\title{
SHALOM SEBAGAI KONSEP KESELAMATAN YANG HOLISTIK
}

\author{
Tolop Oloan Marbun, M.Th., M.Pd. \\ Sekolah Tinggi Teologi Pelita Dunia, tolopmarbun@gmail.com
}

\begin{abstract}
This aricle's title is "shalom" as concept of holistic of salvation. The concept of salvation is very vital in Christianity. Christians put more attention to the ultimate salvation which is saved from the penalty of sin. The method is inductve method through library approach. The result of this article will be holistic salvation such as physical salvation, material salvation, relation salvation, moral salvation and the ultimate God's will.
\end{abstract}

Keywords: Shalom, Salvation, The ultimate God's will.

\begin{abstract}
Abstrak: Artikel ini berjudul, shalom sebagai konsep keselamatan yang holistik. Konsep keselamatan sangat penting dalam dalam kekristenan. Konsep keselamatan selama ini lebih dominan adalah keselamatan yang mengacu pada selamat dari hukuman dosa. Metode yang digunakan dalam artikel ini metode induktif dengan pendekatan studi pustak. Hasil dari penelitian adalah keselamatan yang holistik meliputi fisik, materi, hubungan sosial, moral dan kehendak Allah yang paling akhir.
\end{abstract}

Kata Kunci: Shalom, Keselamatan, Kehendak Allah paling akhir.

\section{Pendahuluan}

Kata "shalom" sering diucapkan sebagai ucapan salam dan sapaan oleh umat Kristen ketika bertemu, ketika mengawali sebuah pertemuan, ketika mengawali sebuah pembicaraan dalam pertemuan. Dalam konteks ini, kata "shalom" dimaknai sebagai ucapan religius. Pemaknaan yang demikian adalah pemaknaan yang terbatas karena kata "shalom" meliki makna keselamatan secara holistik. 
J. Steven Harper menegaskan bahwa para teolog bergumul di antara misteri yang sulit diucapkan dan penjelasan yang berlebihan.1 Keselamatan masih menjadi misteri sampai saat ini. Tidak ada seorangpun yang turun dari sorga dan memastikan apakah keselamatan hilang atau tidak, semua masih berdasarkan penafsiran, pilihan dan kesepakatan.2 Pengikut Calvinis memilih ajaran Calvin dan sepakat, pengajaran Calvinislah yang terbaik3. Pengikut Armenian memilih ajaran Armenian dan sepakat bahwa pegajaran Armenius yang lebih Alkitabiah benar.4

Menurut Pillip Schaff kedua-duanya benar apa yang Calvinis dan Armenian ajarkan dan kedua-duanya salah tentang apa yang mereka sangkali. Calvinis mengajarkan bahwa anugerah hanya untuk orang pilihan, sedangkan Armenian mengajarkan anugerah untuk semua orang dengan syarat iman. Calvinis menyangkal penebusan untuk semua orang, Armenian menyangkali ketetapan Allah sebelum penciptaan bahkan sebelum kejatuhan manusia.5

Perdebatan ini sebenarnya dimulai dari gereja mula-mula. Para pemimpin gereja mula-mula menegaskan bahwa setiap orang bercaya harus bediri teguh dalam iman dan tetap setia dalam penganiayaan dan jangan seorangpun sampai menyangkal iman.6 Irenaeus mengajarakan supaya Gereja menciptakan suasana ketakutan dan ketidakpastian akan keselamatan dengan tujuan supaya jemaat tidak ada yang murtad.7

Agustinus adalah orang pertama yang membuat pengajaran Jaminan Keselamatan secara sistematis. Agustinus mengajarkan bahwa salah satu pemberian Allah adalah karunian penjagaan (perseverance of the saints). 8 Dukunganya adalah doa bapa kami.9 Agustinus juga menegaskan, ketika Allah 2002), 55 .

1Michael S. Horton, at.all., Four Views on Eternal Security (Grand Rapids: Zondervan,

2 Dogma is a Greek Word, referring to what seems correct to a person, that which that person sets forth as his convince. Hendrikus Berkhof, Introduction to the study of dogmatics (Grand Rapids: Eerdmans, 1914).

3 James White, The Potter's freedoms: A Defense of the Reformation and a Rebuttal of Norman Geisler's Chosen but Free (Calvary Press: 2009), 329-337.

4 Horton, Four Views, 137-187

${ }_{5}$ Phillip Schaff, Nicene and Post Nicene Father Series 1, Vol. 5 (Grand Rapids: Christian Classics Ethereal Library),1:509-523.

${ }_{6}$ Gregg, 543

7 Gregg R. Allison, Historical Theology: An Introduction to Christian Doctrine (Grand Rapids: Zondervan, 201), 543-544.

8 Perseverance of the saint means that all those who are truly born again will be kept by God's power and will preserve as Christians until the end of their life. Wayne Grudem, Systematic Theology: Introduction to Biblical Doctrine (Grand Rapids: Zondervan, 1994), 788.

9 Allison, Historical Theology,545 
memberikan garansi kepada orang percaya, tidak ada seoragpun yang jatuh, mereka akan tetap dalam kekudusan sampai pada akhirya.10

Tomas Aquinas bersandar pada teologi Agustinus untuk mengembangkan teologinya, sekalipun demikian, Aquinas berbeda dengan pendahulunya. Bagi Auquinas jaminan keselamatan adalah karunia Ilahi. Perseverance adalah panggilan untuk setia dalam kebaikan sampai pada akhirnya. Perseverance tidak hanya membutuhkan habitual grace11 dan juga pertolongan Allah yang akan mempertahankan orang saleh sampai pada akhirnya.12

John Calvin menegaskan bahwa Allah membawa orang percaya kepada Kristus dan menjaga mereka sampai masuk dalam keselamatan. Keselamatan adalah sepenuhnya karya Allah, tidak ada usaha atau perbuatan baik manusia yang bisa menambahkan keselamatan.13

Setelah setengah abab kematian Calvin, ada banyak kontraversi di antar Teologi Calvinis, yang dipimin oleh Jacbous Armenius.14 Pada mulanya dia adalah seorang Calvinis yang sangat kuat, dia belajar dari menantu Calvin di Beza. Namun, setelah kekalahannya berdiskusi dengan Koornheert, Armenius berubah.15 Alasannya, karena ia masih memiliki banyak pertanyaan tentang asumsi-asumsi Teologi Reformed.16 Armenius keberatan dengan pengajaran Calvin tentang pemilihan dan reprobation. Armenius memodifikasi pengajar tersebut ke dalam teologinya17 dan mejadi pusat dari pengajaranya. 18

Paul Tillich memiliki pendekatan yang berbeda Calvin dan Armenius. Menurut Tillich, pada umumnya orang memahami keselamatan selamat dari

10 Ibid., 547.

11 Pengertian Habitual Grace secara literal adalah anugerah yang membuat berkenan, Alister McGrath, Christian Theology: An Introduction (Oxford and Cambridge: Blackwell, 1994), 356. Menurut Aquinas, Allah tidak bisa langsung hadir dalam jiwa manusia, maka Allah memembuat tabiat yang supranatual dalam jiwa manusia. Hal ini membuat jiwa manusia berubah dan membuat jiwa manusia berkenan kepada Allah dan memiliki kerinduan berbuat baik. Tomas Aquinas, Summa Theologica, Kindel Version, (e-artnow,2013), 1st pt. of pt 2, q.109, art.6 12Allison, Historical Theology, 548-549

13 Ibid., 550-551

14 Ibid., 554

15 Paul Enns, The moody Handbook Theology: Revised and Expanded (Chicago: Moody Press, 2014),523

16 Martin Davie at. All., (ed). New Dictionary of Theology, Historical and Systematic

(Illinois: IVP Academic, 22016), 64.

17 Enns, The moody Handbook, 523

18 Davie, New Dictionary, 64 
the ultimate negativities.19 Tillich menegaskan bahwa seorang selamat atau kehilangan keselamatan semua bergantung kepada pembatas pengertian keselamatan.20

Tillich memahami keselamatan berdasarkan kata "salvus" (atau sembuh).21 Menurut Tillich keselamatan ada]lah kesembuhan. Kesembuhan dalam konteks ini reunityz2. Pemulihan hubungan Allah dan manusia yang sudah terpisah dari dosa. Kesembuhan yang paling esensial menurut Tillich adalah kesembuhan dari kebiasan dari self-destructive.23 Merusak diri sendiri tidak hanya berdampak negatif pada saat di bumi, tetapi juga berdampak pada hidup yang akan datang.

Erastus Sabdono memulai konsep keselamatan dari pengertian keselamatan. Sabdono menyatakan bahwa terhindar dari neraka dan penghakiman yang kekal itu adalah buah keselamatan, bukan keselamatan itu sendiri. Keselamatan adalah usaha Allah untuk mengembalikan manusia kepada rancangan-Nya semula. Pengertian ini menunjukkan bahwa keselamatan itu proses.24

Berdasarkan pemaparan di atas, dari gereja mula-mulai sampai pada saat ini keselamatan fokus pada keselamatan dari hukuman dosa (atau neraka). Tillich memberikan pendekatan yang berbeda karena menurut Tillich keselamatan adalah kesembuhan. Menurut Sabdono masuk sorga bukanlah keselamatan, keselamatan usaha Allah mengembalikan manusia pada rencanNya semula. Dengan kata lain, konsep keselamatan tergantung pada bagaimana seseorang memaknai kata "keselamatan."

Floyd Barackman menegaskan bahwa ketika tujuan utama belajar teologi adalah memahami ajaran Alkitab secara objektif.25 Berdasarkan pernyataan Barackman, penulis melakukan pendekatan "shalom" sebagai konsep keselamatan yang holistik di dalam Perjanjian Lama (PL) yang

${ }_{19}$ Paul Tillich, Systematic Theology (Chicago: The University of Chicago Press, 1962), 2:165. The Ultimate negativities adalah hal-hal negatif yang paling akhir yang timbul dalam pikiran orang ketika berbicara keselamatan dalam konteks Alkitab, yaitu selamat dari neraka. 20 Ibid., 165-166

21 Ibid.

22 Ibid. Manusia dipersatukan kembali dengan Allah.

23 Ibid.

24Erastus Sabdono, Apakah Keselamatan Bisa Hilang? (Jakarta: Rehobot Literatur, 22017), 1-6

${ }_{25}$ Floyd H. Barackman Practical Christian Theology (New Jersey: Fleming H. Revell Company,1984), 6. 
kemudian dilanjutkan dengan kata "Eirene" sebagai konsep keselamatan dalam Perjanjian Baru (PB).

Penulis menggunaka metode induktif 26 dengan model kualitatif studi pustaka. Penulis memulai dari asumsi-asumsi yang berkaitan dengan judul artikel. Kemudian penulis akan menentukan landasan berpikir untuk memutuskan pemikiran yang menjadi solusi dalam artikel ini.27 Sehingga menghasilkan shalom sebagai konsep keselamatan meliputi fisik, materi, hubungan sosial, moral dan kehendak Allah yang paling akhir serta prakteknya dalam konsep Israel.

\section{Metode Penelitian}

Penelitian ini menggunakan pendekatan kualitatif, secara khusus kajian pustaka. Pendekatan ini diambil untuk memperoleh pemahaman kualitatif yang valid dan komprehensif bagi topik yang dibahas dalam penelitian ini.

\section{Shalom sebagai konsep keselamatan dalam PL.}

Konsep keselamatan dalam kekristenan tidak terlepas dari konsep keselamatan dalam PL. Oleh sebab itu penulis akan memulainya dengan konsep keselamatan dalam konteks PL kemudian melihat titik temunya dengan keselamatan dalam PB.28

\section{Shalom dalam konteks fisik dan materi}

Kata "shalom" sebagai ucapan salam ketika bertemu dengan seseorang.29 Ketika Yusuf menyapa saudara-saudaranya yang datang ke Mesir. Yusuf mengucapkan "shalom" (Kejadian 43:27-28).30 Kata "shalom" juga diucapkan bagi mereka yang melakukan perjalanan dan perpisahan.31 Ucapan "shalom" dalam konteks ini berarti semoga sukses dan selamat sampai tujuan.32

${ }_{26}$ Charler Hodge, Systematic Theology (Grands Rapids: Christian Classic Ethereal Library, 2005), 1:21.

27 Ibid

${ }_{28}$ George Barker Stevens, The Christian Doctrine of Salvation (New York: Charles Scribner's son, 1905), 1.

${ }_{29}$ Luke Emeka Ugwueye, "Shalom: A Study of Concept of Peace in the Old Testament", International Journal of Theology and Reformed, (2010: Vol. 2).74. ${ }_{30}$ Perry B. Yoder, Shalom: The Bible's Word for Salvation, Justice and Peace, (Indiana: Evangel Publishing House, 1987), 11.

31Ibid.

${ }_{32}$ Ulrich Duchrow \& Gerhard Liedke, Shalom: Biblical Perfective on Creation, Justice and Peac, Trans. WCC Publictios, (Geneva: WCC Publications, 1989),114. 
Kata "shalom" digunakan untuk menanyakkan kabar. Ketika digunakan menanyakkan kabar, shalom artinya baik-baik saja.33 Ketika Yitro datang menemui Musa, Yitro menanyakan kabar Musa, putrinya dan cucu-cucunya.34 Ketika Yusuf bertanya tentang keberadaan Yakub (Kejadian 37:14).35 Yusuf menanyakan keberadaan kekayaan (atau materi) yang dimiliki Yakub dan juga kesehatan Yakub secara fisik. Jadi shalom dalam konteks ini keberadaan seseorang baik secara fisik dan material36

Shalom juga berarti harapan sukses. Kata ini dipakai dalam konteks imam Eli memberkati Hana. Ketika imam Eli berkata “...pergilah dengan shalom..." (1 Samuel 1:17). Shalom dalam konteks ini artinya Tuhan memberkati Hana dan mengabulkan doa Hana.37 Shalom juga berarti berkelimpahan. Ketika seorang imam mendoakan umat Isreal, Imam akan berkata "Allah memberikan engkau 'shalom"', artinya Allah memberkatimu berlimpah-limpah.38

Shalom juga secara fisik bisa berlaku pada hal yang sedang berlangsung dan yang akan datang. Ketika Yakub berdoa di Bethel. Yakub berdoa supaya ketika Yakub tiba di kampung halamannya, ada damai antara Yakub dan Esau.39 Jadi shalom adalah doa untuk keadaan damai untuk hal-hal yang sedang berlangsung dan juga hal-hal yang akan datang.40

Kata "shalom" berarti selamat dari hal-hal yang berbahaya secara fisik sehingga memiliki rasa aman secara fisik.41 Bahaya fisik seperti perang, sakit, kelaparan, perampokan, atau kejahatan lainnya yang membahayakan.42 Dalam konteks perang, kata "shalom" artinya kembali dengan damai atau kembalilah dengan penuh kemenangan (1 Raja-raja 1:17).43 Ketika tentara Israel pulang dengan penuh kemenangan, sama artinya pulang dengan "shalom."

Secara negatif, kata "shalom" artinya bebas dari perang, sedangkan secara positif, semua berjalan lancar.44 Bangsa Israel pada saat itu dikelilingi bangsa-bangsa yang memusuhi mereka, kapan saja bisa terjadi perang, hal ini

33YYoder, Shalom: The Bible's Word 12.

34 Duchrow dan Liedke, Shalom: Biblical Perfective on Creation,113.

35Yoder, Shalom: The Bible's Word, 11.

36Ugwueye, Shalom: A Study of Concept, 78.

37Ibid.

38 Yoder, Shalom: The Bible's Word,12

39Ibid., 11-12.

40Duchrow dan Liedke, Shalom: Biblical Perfective on Creation,113.

41 Ibid, 114.

42 Yoder, Shalom: The Bible's Word, 13.

43Ibid., 12.

44Ibid., 14. 
membuat Bangsa Israel tidak nyaman.45 Ketika bangsa Israel bebas dari perang, semua berjalan baik-baik saja dan tidak ada ancaman ataupun gangguan maka pada saat itulah terjadi shalom dalam arti negatif dan positif.

Dalam konteks ini "shalom" sebagai konsep keselamatan secara fisik dan materi. Keselamatan secara fisik bebas dari penyakit, bebas dari perang atau bebas dari hal-hal yang membahayakan secara fisik. Keselamatan secara materi bebas dari keurgian, perampokan dan perampasan.

\section{Shalom dalam konteks hubungan sosial.}

Shalom membawa nilai positif, keadilan dan kenikmatan dalam setiap hubungan sosial.46 Kata "shalom" dalam hubungan sosial berarti memiliki hubungan yang baik dengan sesama, dengan masyarakat, atau antara bangsa ataupun kelompok (1 Raja 5:12). 47 Shalom digunakan dalam aturan yang baik dalam bangsa Israel dan juga perjanjian dengan bangsa-bangsa lain (Bilangan 25:12, Yehezkiel 34:26; 37:26).48 Ketika aturan yang baik tersebut dijalankan, maka terjadilah hubungan sosial yang harmonis, atau hubungan yang shalom

Shalom dalam arti keadilan biasanya selalu dikaitkan dengan kebenaran.49 Dalam Mazmur 35:27 shalom berpasangan dengan kebenaran. Pemazmur meminta pembebasan kepada Allah dari musuh yang menakutkan. Pembebasan terhadap yang lemah, yang miskin dan juga yang tertekan. Jadi ketika Allah membebaskan Israel, keadilan sudah dilaksanakan, hasilnya adalah shalom.50

Dalam konteks ini "shalom" sebagai konsep keselamatan dalam hubungan yang damai dengan sesama manusia. Hubungan yang baik ini menghasilkan kerukunan dan keharmonisan. Keselamatan dalam hal ini bebas dari petikaian, kebencian, keributan dan hal-hal yang merusak kedamaian sosial.

\section{Shalom dalam konteks moral}

Kata "shalom" memiliki penekanan dalam moral. Dalam hal ini ada dua penggunaan kata "shalom." Yang pertama kejujuran atau integritas dan yang

45Ugwueye, Shalom: A Study of Concept, 73.

${ }_{46} \mathrm{Ugwueye}$, Shalom: A Study of Concept of peace, 75

47Duchrow \&Liedke, Shalom: Biblical Perfective on Creation, 147.

48 Ibid.

49 Damai selalu berkaitan dengan keadialan, termasuk dengan kasih. Kedamaian pasti tercipta, ketika ada keadilan. John Macquarrie, The concept of peace (New York: Happer \& Row Publisher, 1973), 1-3.

50 Yoder, Shalom: The Bible's Word, 14-15. 
kedua secara moral tak bercatat dan tak bercela.51 Dalam konteks ini, orang Israel harus membuang dusta dan kemunafikan, menjungjung kejujuran, integritas dan keterusterangan. 52

Dari pemaparan kata "shalom" dalam praktik bangsa Israel, kata "shalom" mengacu kepada materi dalam dunia ini; seperti harta dan kekayaan, hubungan bangsa Israel dengan sesamanya sehingga terjadi keharmonisan, dan karakter bangsa Israel secara pribadi; memiliki moral yang tinggi dan etika yang benar.

Dalam konteks ini "shalom" sebagai konsep keselamatan memiliki moral dan etika yang baik. Ketika bangsa Israel memiliki etika dan moral yang baik, Bangsa Israel selamat dari konsekwensi ketidak jujuran, selamat dari akibat dari moral bercela dan bercacat. Konsekwensi ini bisa datangnya dari orang-orang yang ada disektar dan juga hukuman dari Allah.

\section{Shalom sebagai kehendak Allah paling akhir}

Shalom berarti bagaimana seharusnya seseorang hidup menurut kehendak Allah. Shalom menjadi simbol rencana dan kehendak Allah terhadap dunia ini. Kehendak Allah adalah supaya umat-Nya bisa menikmati suasana yang "shalom" dalam kehidupan mereka. Dalam Yesaya 2:2-4 menjelaskan bagaimana bangsa Israel hidup dalam shalom. Sekalipun, kata "shalom" tidak muncul, tetapi merupakan penjelasan dari kata "shalom." 53

Gambaran shalom menunjukkan umat-Nya mengenal hukum Allah dan belajar jalan-Nya Allah. Ini adalah cara bagaimana seharusnya umat-Nya hidup. Dari pernyataan ini ada dua kunci utama yaitu ketaatan umat-Nya dan Allah memerintah dalam penghakiman-Nya. Sederhananya, ketika kehendak Allah yang ultima terlaksana atas bangsa Israel, maka shalom biasa dialami oleh umat-Nya.54

"Shalom" adalah hasil perbuatan Allah berdasarkan perjanjian dan hasil dari kebenaran (Yesaya 32:17), secara khusus dalam perjanjian Damai. (Bilangan 25:5; Yesaya 54:10; Yehezkiel 34:25; Maleakhi 2:5). Damai ini menggambarkan kesepakatan di antara musuh, seperti Isak dan Abimelek (Kejadian 26:19) dan juga manusia dengan Allah (Kejadian 15:15).55

51 Yoder, Shalom: The Bible's Word, 16.

${ }_{52}$ Duchrow \&Liedke, Shalom: Biblical Perfective on Creation, 113.

53Yoder, Shalom: The Bible's Word, 18.

54Ibid., 19.

55Ugwueye, Shalom: A Study of Concept,75. 
Dalam konteks ini "shalom" sebagai konsep keselamatan yang menunjukkan ada perdamaian antara manusia dan manusia, terutama perdamaian antara Allah dan manusia. Perdamaian Allah dan manusia adalah kehendak Allah yang paling akhir dari perjanjian yang dilakukan oleh Allah.

\section{A. Keselamatan adalah shalom dalam praktek kehidupan bangsa Israel.}

Orang Israel percaya, bahwa hanya Allah saja yang bertindak adil. Keadilan adalah dasar dari kerajaan Allah yang mengatur dunia ini. Melakukan keadilan adalah dasar dari Allah sebagai Allah.56 Keadilan Allah tidak berdasarkan perbuatan, melainkan berdasarkan kebutuhan. Keadilan bertujuan untuk menjawab kebutuhan orang lemah, orang miskin dan orang yang tertekan.57 Ketika Allah menjawab kebutuhan orang lemah mereka selamat dari kelemahannya, demikian juga orang yang miskin dari kemiskinannya dan orang tertekan dari tekanan yang dialami.

Keselamatan digambarkan dua illustrasi besar dalam Alkitab. Yang pertama keselamatan bangsa Israel dari tanah mesir. Yang kedua keselamatan melalui Yesus Kristus58. Peristiwa keluaran sebagai fondasi keselamatan karena menggambarkan belaskasihan dan kasih Allah paling terdalam.59

Dalam kitab Keluaran 2:23-25 ada dua poin penting. Yang pertama keluaran adalah tindakan keselamatan. Kedua peristiwa keluaran adalah tindakan penyelamatan dari Allah karena bangsa Israel tertekan (atau dijajah). Dari kedua poin ini, keselamatan adalah pembebasan bangsa Israel dari perbudakan, hal ini juga merupakan ekspresi dari keadilan, menolong yang membutuhkan, mengoreksi ketidakadilan dan membawa shalom.60

Shalom juga berkaitan dengan "kurban perdamaian." 61 Ketika bangsa Israel berdosa, mereka harus membawa kurban. Ketika darah kurban itu ditumpahkan sebagai penebusan, maka terjadilah rekonsiliasi antara bangsa Israel dengan Allah. (Imamat 3; 7:11). Ketika mereka berdamai dengan Allah, mereka selamat dari murka Allah atau selamat dari hukuman dosa yang mereka perbuat.

56Yoder, Shalom: The Bible's Word, 39.

57Ibid.

58 Penulis akan membahas dalam subjudul berikutnya.

59 Yoder, Shalom: The Bible's Word, 78.

60Ibid.

61Ibid., 75-76. 
Salah satu nama Mesias disebut "Raja Damai” (Yesaya 9:6). Dia adalah Raja yang membawa keutuhan, Dia juga Firman Allah, Dia juga yang menjadi kurban paling akhir yang membawa damai dan penebusan bagi seluruh umat manusia.62 Dalam konteks PL, Mesias adalah mesias politik yang akan memimpin di Yerusalem, yang akan menyelamatkan Yerusalem dari musuhmusuh politiknya, sekaligus penghapusan dosa secara total.63

\section{Eirene sebagai konsep keselamatan dalam PB}

Kata "eirene" memiliki arti yang sama dengan "shalom" yaitu keadaan yang baik secara materi dan fisik, hubungan yang baik dan karakter moral yang baik.64 Eirene juga dipakai dalam kata sapaan termasuk dalam kata pembukaan dan penutup surat sebagai ucapan berkat bagi pembacanya. Yesus juga mengucapkan "eirene" setelah menyembuhkan seorang wanita (Markus 5:34).65 Eirene dalam ucapan Yesus sebagai ucapan berkat atas kesembuhan wanita tersebut.

Dalam hubungan "eirene" memiliki arti yang sama dengan "shalom" yaitu bebas dari berbagai masalah dan bebas dari perang. Kata "eirene" dalam konteks relasi menggambarkan kehadiran hubungan yang baik. 66 Hubungan yang baik akan tercipta ketika konflik bisa diatasi dengan baik.

Kata "eirene" mengacu pada moral Kristen (Roma 8:6, 14:17, 15:13; Galatia 5:22; 2 Timotius 2:22; 1 Petrus 3:11; 2 Petrus 3:14). Penggunaan kata "eirene" dan "shalom" dalam konteks ini memiliki persamaan yaitu, kualitas moral. Perbedaannya, "eirene" adalah orang yang suka membuat damai sedangkan "shalom" memiliki integritas.67

Perbedaan berikutnya penggunaan secara teologis. Dalam PB sering ditemukan "the God of peace" (dalam Bahasa Indonesia: Allah sumber damai sejahtera Roma 15:33; 16:20; 2 Korintus 13:11). Ekspresi kata "eirene" dalam PB seperti the peace of God, the peace of Christ. 68

Dalam PB juga ditemukan Injil damai sejahtera (Efesus 2:17; 6:15; KPR.10:36). Injil yang membawa perdamaian bagi manusia dengan Allah dan manusia dengan sesamanya. Roma 1:16-17 menegaskan bahwa Injil adalah

${ }_{62}$ Ibid., 76.

63Halmer Ringgren, The Messiah in the Old Testament (London: SCM Press LTD, 1967), 11-12

64 Yoder, Shalom: The Bible's Word, 19.

65 Ibid, 20.

66 Ibid.

67 Ibid.

68 Ibid. 
kekuatan Allah yang menyelamatkan semua orang. Kata "eirene" menjadi konsep sangat penting dalam PB karena berbicara tentang kekuatan Allah dan kabar baik bagi semua orang.69

Signifikasi teologis kata "Eirene" mengacu pada kematian dan kebangkitan Yesus Kristus. Yesus Kristus membawa perdamaian dengan dua cara. Yang pertama digambarkan dalam Roma 5:1-11, yaitu: hasil dari justification adalah berdamai dengan Allah. Misi utama Yesus adalah memperdamaikan manusia dengan Allah. Manusia sudah bermusuhan dengan Allah karena dosa. Manusia tidak bisa memperdamaikan dirinya sendiri. Allah berinisiatif untuk mentranformasi hubungannya yang Ilahi dengan manusia melalui Yesus Kristus.70 Jadi perdamaian pertama adalah Allah mentransformasi hubungan Ilahi dengan manusia. Sebelumnya manusia sebagai musuh Allah, sekarang manusia sudah diperdamaikan dengan Allah melalui Yesus Kristus.

Kematian Yesus Kritus tidak hanya mentransformasi hubungan Ilahi manusia dengan Allah, tetapi juga manusia dengan sesamanya (Efesus 2:1417; Kolese 1:20). Kematian Yesus Kristus menghapuskan pemisahan antara bangsa Yahudi dan non-Yahudi, sekarang kedua-duanya menjadi sama secara spritual.71 Jadi perdamaian yang kedua adalah kematian Kristus membawa transformasi hubungan dengan sesama manusia. Manusia harus berdamai dengan sesamanya.

Titik temu konsep keselamatan dalam PL dan PB terdapat pada kata "eirene" dan "shalom." Kata "eirene" memiliki arti yang sama dengan "shalom" yaitu, keselamatan secara fisik dan materi dari hal-hal yang merugikan dan membahayakan, keselamatan dalam pergaulan melalui hidup berdamai dengan sesama dan lingkungan, dan juga keselamatan secara spiritual.

Perbedaan yang signifikasi antara kata "eirene" dengan "shalom" adalah Injil damai sejahteran, kematian dan kebangkitan Yesus Kritus. Hasil dari kematian dan kebangkitan Yesus Kristus adalah manusia diperdamaikan dengan Allah sehingga manusia memiliki hubungan Ilahi dengan Allah. Karena manusia sudah diperdamaikan dengan Allah, maka manusia harus hidup damai dengan sesamanya.

Kematian Yesus Kristus merupakan puncak dari realisasi shalom sebagai kehendak Allah yang paling akhir. Kamatian ini sekaligus menjadi

69 Ibid.

70 Ibid.

71 Ibid., 20-21. 
pembeda paling sigfikan antara kata "shalom" dan "Eirene" sebagai konsep keselamatan. "Eirene" sebagai konsep keselamatan mendominasi dalam semua kitab-kitab dalam PB sehingga keselamatan secara fisik, materi dan hubungan dengan sesama kurang mendapat perhatian.

\section{Kesimpulan}

Kata "shalom" tidak hanya sebatas ucapan relegius saja, tetapi juga sebagai konsep keselamatan yang holistik. Keselamatan yang holistik meliputi:

- Keselamatan secara fisik adalah selamat dari berbagai peyakit, selamat dari mara bahaya, selamat dari perang dan selamat dari hal-hal yang merugikan secara fisik.

- Keselamatan secara materi adalah selamat dari hal-hal yang merugikan secara materi, selamat dari kerugian, selamat dari perampokan dan selamat dari hal-hal yang merugikan secara materi.

- Keselamatan dalam konteks sosial adalah ketika tercipat hubungan yang damai, rukun dan harmonis dengan sesama manusia dalam bermasyaratkat dan bernegara.

- Keselamatan dalam konteks moral adalah selamat dari akibat dari moral yang bercela dan bercacat baik dari masyaratkat dan dari Allah.

- Keselamatan dalam kontenks kehendak Allah yang paling akhir adalah ketika Allah berdamai dengan manusia. Puncak realisasi kehendak Allah ini adalah kematian Yesus sebagai kurban perdamaian.

\section{Referensi}

Allison Gregg R. Historical Theology: An Introduction to Christian Doctrine.Grand Rapids: Zondervan, 2011.

Aquinas, Tomas. Summa Theologica, Kindel Version, (e-artnow,20130.

Barackman, Floyd H. Practical Christian Theology. New Jersey: Fleming H. Revell Company,1984.

Berkhof, Hendrikus. Introduction to the study of dogmatics (Grand Rapids: Eerdmans, 1914.

Davie, Martin. at. All., (ed). New Dictionary of Theology, Historical and Systematic. Illinois: IVP Academic, 22016. 
Duchrow, Ulrich dan Liedke, Gerhard. Shalom: Biblical Perfective on Creation, Justice and Peace. Trans. WCC Publictios. Geneva: WCC Publications, 1989.

Enns, Paul. The moody Handbook Theology: Revised and Expanded. Chicago: Moody Press, 2014.

Grudem, Wayne. Systematic Theology: Introduction to Biblical Doctrine.Grand Rapids: Zondervan, 1994.

Hodge, Charler. Systematic Theology. Grands Rapids: Christian Classic Ethereal Library, 2005.

Horton, Michael S., at.all., Four Views on Eternal Security. Grand Rapids: Zondervan, 2002.

Macquarrie, John. The concept of peace. New York: Happer \& Row Publisher, 1973.

McGrath Alister. Christian Theology: An Introduction. Oxford and Cambridge: Blackwell, 1994.

Ringgren, Halmer. The Messiah in the Old Testament (London: SCM Press LTD, 1967.

Sabdono, Erastus. Apakah Keselamatan Bisa Hilang? Jakarta: Rehobot Literatur, 22017.

Schaff, Phillip. Nicene and Post Nicene Father Series 1, Vol. 5. Grand Rapids: Christian Classics Ethereal Library.

Stevens, George Barker. The Christian Doctrine of Salvation. New York: Charles Scribner's son, 1905.

Tillich, Paul. Systematic Theology. Chicago: The University of Chicago Press, 1962.

White, James. The Potter's freedoms: A Defense of the Reformation and a Rebuttal of Norman Geisler's Chosen but Free (Calvary Press: 2009).

Yoder, Perry B., Shalom: The Bible's Word for Salvation, Justice and Peace. Indiana: Evangel Publishing House, 1987.

\section{JURNAL}

Ugwueye, Luke Emeka. "Shalom: A Study of Concept of Peace in the Old Testament". International Journal of Theology and Reformed. 2010: Vol. 2. 
